\title{
JUURNAL.RU
}

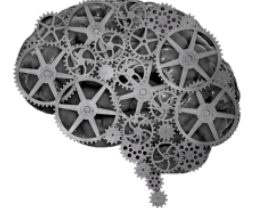

COMPANY GROUP "INTELLEKT"

\author{
Веселова Н.Ю, Савченко А.Е. \\ Кубанский государственный технологический университет \\ Краснодар, Россия
}

doi: 10.18411/1j2016-5-4-02

\section{Проблемы и направления развития туризма в муниципальных образованиях}

Туризм и туристская индустрия обеспечивает потребности граждан в совершении путешествий, они создают новые рабочие места, увеличивают доходы республиканского бюджета и бюджета субъектов РФ, развивают межрегиональные и международные контакты, способствуют рациональному использованию природного и культурного наследия.

Россия и ее субъекты обладает уникальными туристскими ресурсами, что вызывает все увеличивающийся интерес, как россиян, так и граждан иностранных государств к путешествиям по России. Туризм становится одной из приоритетных отраслей экономики Российской Федерации.

Одним из видов туризма и отдыха является новый для России вид рекреации (отдыха на природе) - посещение заповедников, событийных мероприятий, сельских рекреационных зон и др. объектов туристского интереса на конкретной территории.

Роль рекреационных зон в сфере туризма должна ограничиваться следующими направлениями:

- управление рекреационными нагрузками

- планирование, организация и контроль потоков туристов внутри туристской территории;

• организация обслуживания посетителей; 
- создание туристского продукта на территории муниципального образования;

- содержание туристской инфраструктуры;

- просвещение населения и др.

Население, проживающее в пределах объектов туризма и рядом с ними, прежде всего, представлено сельскими жителями. Процесс вовлечения сельских жителей в деятельность муниципального образования в сфере туризма носит комплексный характер. Во-первых, в настоящее время сельское население преимущественно занято на своих личных приусадебных хозяйствах и будет готово работать в сфере туризма при условии, что эта работа станет дополнительным видом его доходной деятельности и даст юридический статус, которого эти люди были лишены, занимаясь только личным хозяйством. Вовторых, сельское население характеризуется низким уровнем образования, культурно-историческими особенностями и отсутствием предпринимательской инициативы, а туризм требует тех навыков, которые сельским жителям несвойственны. Это требует дополнительных затрат на обучение. В-третьих, органы местного самоуправления и национальные парки, как правило, не имеют достаточной квалификации для работы с сельским населением по устойчивому природопользованию.

Тем не менее, туризм оказывает экономическое, политическое, культурное и социальное влияние на жизнь населения, проживающего в рекреационной зоне. Большинство туристских объектов обслуживают не только туристов, но и местных жителей и способныобеспечить, по крайней мере, сезонную или частичную занятость для местных жителей.

Основой развития туризма является частная инициатива и предпринимательский интерес местного населения.

Такая инициатива должна поощряться не только местными администрациями путем создания условий, которые в наибольшей степени будут способствовать развитию предпринимательской и творческой активности 
сельского населения. Механизмы стимулирования местного населения могут быть самыми разными: например, организация конкурсов на право осуществления предпринимательской деятельности на территории объектов туризма; льготное кредитование местными администрациями или фондами социальной поддержки населения проектов в сфере экологически чистого сельского хозяйства или в сфере услуг и т. д.

На территории объектов туризма и по соседству с ними сельское население может получать доход в сфере туризма от следующих видов деятельности:

обустройства туристских маршрутов по заказу местно органов местного самоуправления;

- оборудования и эксплуатации стоянок для туристов;

- работы в качестве гидов и экскурсоводов;

- транспортного обслуживания туристов;

- егерской деятельности (охота, любительское и спортивное рыболовство);

- услуг по прокату туристского снаряжения;

- услуг по размещению туристов и организации ночлега;

- кулинарных услуг для туристов;

- подготовки культурных программ для туристов (народные песни и обычаи);

- кустарных и народных промыслов (обучение и реализация продукции туристам);

- производства и реализации туристам экологически чистых продуктов питания;

- сбора и переработки грибов и ягод и их реализация туристам и т. п.

Указанные виды деятельности могут осуществляться в форме предпринимательства без образования юридического лица, они требуют как 
минимум получения лицензий и заключения договоров с местными органами власти и организациями владеющими объектами туризма.

Для широкого внедрения практики арендных и концессионных отношений на территории муниципального района необходимы гарантии, что местное население будет способно выполнить перед ним свои обязательства. Гарантами здесь могут выступить органы местного самоуправления, например, путем реализации программ обучения местных жителей основам приема и обслуживания посетителей в собственных частных домах или улучшения жилищных условий в частном секторе.

Со стороны муниципального района требуется организационная поддержка, которая может заключаться в информировании местных жителей о планах приема посетителей и туристов, местах прохождения туристских маршрутов и потребностей в тех или иных услугах на маршрутах или в местах приема посетителей.

Таким образом, организация процесса повышения доходов и обеспечения занятости населения в сфере туризма на территории муниципального района и его окружения должна начинаться с конкретных шагов со стороны муниципального района, местных администраций и жителей навстречу друг другу. Основными принципами устойчивого жизнеобеспечения в сфере туризма муниципального района можно считать:

1) ориентацию муниципального образования на привлечение местного населения к обслуживанию посетителей;

2) ориентацию туристской деятельности на удовлетворение потребностей посетителей и получение дохода;

3) информационное обеспечение органов местного самоуправления, населения прилегающих районов и туроператоров о планах и проектах муниципального образования по развитию туризма;

4) привлечение к туроператорской деятельности существующих региональных или национальных туроператоров; 
5) дополнительное обучение и подготовку местных жителей к работе с посетителями объектов туризма силами органов местного самоуправления, или частного сектора;

6) опору объектов туризма при внедрении устойчивого природопользования на органы местного самоуправления;

7) координацию действий по устойчивому использованию туристских ресурсов муниципального образования через общественные координационные органы.

Основой процесса устойчивого жизнеобеспечения является общность интересов сторон в коммерческой, природоохранной и социальной сферах.

Создание условий для развития туризма и отдыха в контексте устойчивого развития муниципального образования (далее - МО)должно проходить в следующих направлениях:

- привлечение инвестиций в инфраструктуру туризма;

- содействие формированию и продвижению конкурентоспособного туристского предложения на территории МО;

- стимулирование предпринимательской активности местного населения в сфере туризма.

Для привлечения инвестиций в создание турпродукта МО можно более эффективно использовать механизм сдачи в аренду земельных участков, объектов туризма, зданий и сооружений, а также туристских маршрутов.

Что касается формирования и продвижения туристского предложения, то здесь роль МО заключается в привлечении возможностей и ресурсов профессиональных туроператоров, которые занимаются организацией внешнего потока туристов. Муниципальные образования должны выступать как бы в роли посредников между местными производителями туристских услуг и турфирмами, помогая первым найти перспективные рынки сбыта, а вторым сформировать конкурентоспособный турпродукт.

Стимулирование предпринимательской активности местного населения 
происходит путем информирования о возможностях бизнеса в сфере туризма на территории МО, а также непосредственно путем привлечения местных жителей к обслуживанию посетителей объектов туризма в рамках отдельных совместных проектов.

Муниципальное образование должно создавать условия для возникновения на своей территории предприятий - точек экономического роста, способных эффективно функционировать и развиваться, обеспечивая, тем самым, личные доходы граждан, новые рабочие места, расширение рынков сбыта, создание новых продуктов и услуг.

Кроме стратегических существует также ряд общих задач территории, решать которые необходимо в любом случае. Все вышеперечисленные направления особенно важно в связи с реформой местного самоуправления.

На основе главной цели и стратегических задач можно выделить несколько основных направлений развития туризма в муниципальном образовании.

1) Создание условий для привлечения инвестиционных ресурсов и развитие инвестиционной привлекательности, а именно:

- привлечение инвестиций в экономику района;

- продвижение района, как инвестиционно-привлекательной территории для развития бизнеса и отдыха, как туристкой территории «Сельский горный туризм»;

- формирование благоприятной инвестиционной среды;

- формирование нормативно-правовой базы, разработка системы льгот, гарантий, схем защиты прав инвесторов и страхования инвестиций.

В результате реализации данного стратегического направления планируется достичь следующих результатов:

- повышение инвестиционной привлекательности; 
- увеличение притока внешних инвестиций на территорию района и втуристскую территорию «Сельский горный туризм»;

- мобилизация внутренних инвестиционных ресурсов;

- развитие финансовой инфраструктуры и кредитной кооперации в районе.

2) Развитие малого предпринимательства как наиболее динамично развивающегося сектора экономики.

Создание благоприятных условий для активизации предпринимательской деятельности, появления новых хозяйствующих субъектов, в том числе малых производственных предприятий и предприятий сферы услуг. Ожидаемые результаты это значительное повышение предпринимательской активности населения, рост числа малых предприятий, в том числе в сфере производства и в сфере оказания услуг, в туристской сфере.

В рамках данного стратегического направления необходима реализация следующих стратегических задач:

- создание инфраструктуры поддержки малого предпринимательства;

- эффективная информационная поддержка субъектов предпринимательства;

- устранение административных барьеров;

- формирование механизмов ресурсного обеспечения субъектов малого предпринимательства (финансово-кредитного, земельного, материального и трудового);

- формирование условий для организации и развития предпринимателями провинциального туризма, как доходной отрасли экономики района (создание рынка туристических услуг);

- создание сети предприятий по оказанию бытовых услуг на территории района;

- развитие придорожного бизнеса и связанной с ним сферы услуг. 
В результате реализации этого стратегического направления ожидаются следующие результаты:

услуг);

- увеличение количества рабочих мест в малом предпринимательстве;

- существенное увеличение налоговых поступлений от малого предпринимательства;

- облегчение доступа субъектов малого предпринимательства к финансово-кредитным ресурсам;

- увеличение объемов и качества продукции, выпускаемой малыми предприятиями, повышение ее конкурентоспособности;

- развитие элементов провинциального туризма в районе;

- повышение доступности рыночной информации для предпринимателей, осуществляющих свою деятельность на территории района;

- повышение уровня культуры предпринимательства (в результате проведения консультаций, семинаров, тренингов).

\section{3) Развитие туризма в МО.}

Данное направление должно способствовать развитию факторов, способствующих превращению МО в центр экологического туризма, туристкой территории в развитии сельского туризма.

В первую очередь это:

- практическое отсутствие промышленности и связанных с ней загрязнений окружающей среды;

- наличие крупных горно-лесных массивов;

- произрастание грибов и ягод, хороший ландшафт, включающий реки и другие водоемы;

- памятники архитектуры; 
- энтокультурные объекты, наличие железной дороги.

Для реализации туристического потенциала необходимо выполнение следующих задач:

- - развитие и реконструкция дорожной сети;

- - строительство комфортабельных гостиниц и гостевых домов с привлечением инвесторов;

- - проведение маркетинговых исследований о емкости рынка туристических услуг в районе и о предпочтительных видах рекреационной активности;

- - создание объектов активного экологического туризма в субальпийских, альпийских лугах;

- - строительство смотровых и обзорных площадок;

- - облагораживание территорий вокруг минеральных и хлоридонатриевых целебных вод,- термальных источников;

- - развитие доступности и строительство дорого и придорожнойинфраструктуры для обзора горных вершины и ущелий,пещер и гротов,- водопадов;

- - оборудовать для временной остановки стоянки древнего человека и место под названием древний Тмутараканский вал;

- - реставрация памятников архитектуры;

- - производство и реализация сувенирной продукции силами малых предприятий;

- - распространение информации о туристической привлекательности района, сотрудничество с туристическими компаниямиоператорами;

- - проведение энтокультурных мероприятий, фестивалей, организация туристических маршрутов;

- - развитие краеведения в районе. 


\section{4) Совершенствование деятельности органов местного самоуправления.}

В условиях реализации нового закона № 131-ФЗ от 06.10.2003 «Об общих принципах организации местного самоуправления в Российской Федерации», резко возросла ответственность органов местного самоуправления за процессы функционирования и перспективы развития муниципальных образований и сельских поселений. Для эффективного исполнения своих полномочий возникла потребность в совершенствовании системы работы органов местного самоуправления, которая реализуется посредством выполнения следующих задач:

- стимулирование социальной и политической активности населения;

- совершенствование бюджетного процесса и управления муниципальной собственностью;

- повышение эффективности работы исполнительной власти;

- повышение качества кадрового состава органов местного самоуправления;

- развитие межмуниципальных и внутрирайонных связей;

- разработка и реализация комплекса мер по формированию положительного имиджа района, активное использование методов и технологий муниципального маркетинга;

- реализация политики сохранения и воспроизводства ресурсной базы района, обеспечение экологической безопасности.

В ходе реализации данного стратегического направления планируется достичь следующих результатов:

- наращивание собственной доходной базы муниципального бюджета за счет в большей степени развития туристкой территории «Сельский горный туризм»;

- оптимизация расходов бюджетной сферы;

- выравнивание расходов местных бюджетов сельских поселений; 
- повышение эффективности управления муниципальной собственностью;

- повышение эффективности взаимодействия между органами государственной власти и органами местного самоуправления на основе разграничения полномочий;

- повышение открытости в деятельности органов местного самоуправления, обеспечение прозрачности процесса принятия решений на местном уровне и результатов исполнения решений;

- привлечение населения к решению вопросов местного значения, управлению муниципальным районом и поселениями;

• оптимизация структуры органов местного самоуправления;

- формирование положительного имиджа МО Апшеронский район и за ее пределами;

- развитие системы межмуниципального и краевого сотрудничества;

- укрепление кадрового состава органов местного самоуправления муниципального района и поселений.

Таким образом, использование данных направлений в социальноэкономического развитии муниципального образования имеющего туристские объекты и ресурсы, позволит снизитьсоциально-экономическою напряженность населения проживающего на этих территориях и повысить качество жизни путем:

- проведения мероприятий по популяризации культурнопознавательных маршрутов, в том числе экскурсионных внутригородских посещений туристами объектов культуры;

- создания краеведческих, музеев, парков отдыха, объектов туристского интереса и т.д.; 
- выделения средства из местного бюджета муниципального образования на повышение уровня знаний экскурсоводов о культуре и традициях района (рабочие встречи, слеты);

- освещения вопросов в СМИ по предотвращению незаконной порубкой леса, т.к.часто приводит к нанесению ущерба памятникам археологии;

- содействия сохранения памятников археологии, в особенности имеющих историческое и культурное значения для общества

- осуществления мероприятия по борьбе с так называемыми «черными копателями», которые варварским способом вывозят культурно-археологические ценности, разрушают курганы и дольмены.

\section{Литература:}

1. Федеральный закон от 06.10.2003 г. № 131-Ф3 «Об общих принципах организации местного самоуправления в Российской Федерации».

2. Федеральный закон от 26.07.2006 г. № 135-Ф3 «О защите конкуренции».

3. Федеральный закон от 22.07.2005 г. № 116-Ф3 (ред. от 13.07.2015) «Об особых экономических зонах в Российской Федерации» (краткое конспектирование по статьям).

4. Федеральный закон от 28.06.2014 г. № 172 «О стратегическом планировании в Российской Федерации».

5. «Об особых экономических зонах в Российской Федерации» (краткое конспектирование по статьям). Сущность, значение, понятийный аппарат, механизм функционирования.Ф3 от 22.07.2005 г. № 116-Ф3 (ред. от 13.07.2015).

6. О стратегическом планировании в Российской Федерации ФЗ от 28.06.2014 г. №172. 
7. Постановление о проекте закона Краснодарского края «О стратегическом планировании в Краснодарском крае» от 21.10.2015 г. «1933-П».

8. Андреева Н.В. Александрова Е.Н., Гребнев И.Д. Развитие инновационной системы на принципах открытых инноваций: национальный и региональный контекст. Теория и практика общественного развития. ООО Издательский дом «ХОРС» г. Краснодар - 2012. $\square$ № 3.

9. Андреева Н.В. Шевченко И.В., Александрова Е.Н. Совершенствование программы инновационного развития Краснодарского края. Региональная экономика: теория и практика. ООО Издательский дом «ХОРС» г. Краснодар - 2013. $\square$ № 3 .

10. Веселова Н.Ю. Погребняк В.С. Показатели эффективности органов местного самоуправления. Проблемы экономики, организации и управления в России и в мире: Материалы VIII международной научнопрактической конференции (28 апреля 2015г.). - Отв. редактор Уварина H.B. - Прага, Чешская республика: Изд-во WORLDPRESSs..r.o. 2015.-263 c.

11. Нагимова А.М. Социологический анализ качества жизни населения: региональный аспект. - Казань: Казан.гос. ун-т, 2010. - 306 с.

12. Оганесян Т.Л., Веселова Н.Ю. Конструкция и эффективность управления деятельностью органов местного самоуправления. Научный вестник Южного института, №1(9), 2015.

13. Эффективность управления соц. - эконом. развитием административнотерриториальных образ.: Моногр. / И.В. Дуканова.; Под ред. проф. В.И.Терехина. -М.:НИЦ ИНФРА-М, 2013-316с. 